\title{
Dysregulation of Endothelin-1: Implications for Health Disparities in Alzheimer's Disease
}

\author{
Donald J. Alcendor
}

Center for AIDS Health Disparities Research, Department of Microbiology, Immunology and Physiology, School of Medicine, Meharry Medical College, Nashville, TN 37208, USA; dalcendor@mmc.edu

\begin{abstract}
Alzheimer's disease (AD) and related dementias disproportionately impact racial and ethnic minorities. The racial and ethnic disparities in AD could be explained by differences in cerebral vascular disease pathology. Endothelin-1 (ET-1) is a potent vasoconstrictive peptide that regulates smooth muscle, endothelial cell, and pericyte contractions that may result in cerebral vascular constriction, leading to cerebral hypoperfusion; over time, ET-1 may result in neuronal injury contributing to the pathology of AD. Upregulation of the ET-1 system has been observed in African Americans when compared with non-Hispanic Whites. The role of the ET-1 system as a driver of ethnic disparities in AD requires further investigation. Targeting of the ET-1 system as a therapeutic intervention that could impact AD progression also needs further study. Dysregulation of ET-1 in Hispanic/Latino populations largely have been unexplored. Genetics linking ET-1 dysregulation and racial disparities in $\mathrm{AD}$ also needs further investigation. In this review, I examine how $\mathrm{AD}$ effects underserved minority populations and how dysregulation of the ET-1 system specifically predisposes ethnic minorities to AD. In addition, I examine the molecular interactions of the ET-1 system and amyloid beta, the role the ET- 1 system in neurodegeneration, potential therapeutics for ET-1 dysregulation, and the impact on AD progression.
\end{abstract}

Keywords: Endthelin-1; Alzheimer's disease; infection; mortality; minorities; health disparities; health inequities; African Americans; Hispanics/Latinos; non-Hispanic Whites

\section{Background/Introduction}

Alzheimer's disease (AD) and related dementias (ADRD) disproportionately impact racial and ethnic minority and socioeconomically disadvantaged adults [1-5]. Racial and ethnic disparities in $\mathrm{AD}$ could be explained by differences in vascular disease pathology. Upregulation of the endothelin system is present in African Americans (AAs) when compared with non-Hispanic Whites (NHWs) [6]. Endothelin-1 (ET-1) is a potent vasoconstrictive peptide that is released basolaterally primarily by endothelial cells to induce vascular smooth muscle cells and pericyte contractions [7-9]. Pericytes expressed BQ-123-sensitive $\mathrm{ET}_{\mathrm{A}}$ receptors for endothelins, as evidenced by ${ }^{125} \mathrm{I}$-Et-1 binding experiments [10]. Dysregulation of the endothelin system occurs in AD. However, AAs experience higher vasoconstriction-mediated blood pressure in response to acute stress than NHWs. A study by Treiber et al. that examined hemodynamic and plasma ET-1 levels in AA and NHW males revealed that AAs had higher resting plasma ET-1 levels and a greater increase in ET-1 in response to stressors [6]. The data supports the notion that racial differences exist in hemodynamic reactivity to stress between AAs and NHWs [6]. AA adults with hypertension have been shown to have significantly higher ET-1 levels than normotensive AAs and NHWs [6]. Ergul et al. discovered that AAs have a higher ratio of vasoconstriction-promoting ET receptors in saphenous veins when compared with NHWs, regardless of whether they were hypertensive, which implicates racial differences in peripheral vascular resistance and diminished vasodilatation in response to environmental stress [11]. These findings 
suggest that AAs are at higher risk for cardiovascular disease than NHWs, which also increases their risk of dementia. Diabetes mellitus (DM) is associated with an increased risk of cognitive decline and AD later in life. Studies have shown that type 2 DM (T2DM) nearly doubles the risk of AD, and it is well known that a health disparity exists among AAs for T2DM when compared with NHWs [12]. Signal peptide-CUB-EGF-like-containing protein 2 (SCUBE2) has been shown to be upregulated in atherosclerotic human coronary artery disease [13]. Ali et al. examined SCUBE2 expression in T2DM patients with dyslipidemia and found that upregulation of SCUBE2 expression in dyslipidemic T2DM is associated with higher levels of ET-1 when compared with controls [13]. Kostov et al. examined serum concentrations of ET-1 and matrix metalloproteinases-2, -9 in pre-hypertensive and hypertensive patients with T2DM [14]. They demonstrated increased levels of ET-1 in patients with T2DM when compared with controls, suggesting that high levels of ET-1 could lead to long-lasting increases in blood pressure and clinical manifestation of hypertension [14]. Palmer et al. revealed that ET-1 levels are elevated in $\mathrm{AD}$ and are upregulated by amyloid $\beta(\mathrm{A} \beta)$; they also demonstrated that endothelin-converting enzyme-2 (ECE-2) is upregulated by $A \beta$, and its expression is elevated in $A D$ post-mortem brain tissue when compared with controls [15]. Furthermore, ET-1 expression is induced by hypoxia or ischemia caused by pericyte-mediated constriction of brain vascular capillaries [16]. Here, I examine the role of the ET-1 system in the development of neuronal injury that contributes to the pathology of $\mathrm{AD}$ and possible ADRDs.

\section{Underserved Minority Populations and AD}

Regardless of the health disparities associated with $\mathrm{AD}$ among ethnic minorities, large population-based studies that examined the pathobiology of AD have been performed with predominantly NHWs, resulting in extrapolation of research findings to minority populations $[17,18]$. Aging and genetics are important risk factors; however, other demographic factors in the United States (U.S.) are rising for $\mathrm{AD}$, including a surge in Hispanic/Latino (H/L) populations [19,20]. Several studies reveal a higher prevalence of $\mathrm{AD}$ in AAs and $\mathrm{H} / \mathrm{Ls}$ [21-23]. Approximately $12 \%$ of older adults in the $\mathrm{H} / \mathrm{L}$ population are diagnosed with $\mathrm{AD}$, which is the highest among all ethnic groups in the U.S. and represents an H/L health disparity [24,25]. Despite genetic and cultural diversity among H/L populations, they display an earlier age of onset when compared with NHWs [26,27]. Vega et al. examined the interplay between social determinants of health, co-morbidities, and genetic factors associated with $\mathrm{AD}$ in $\mathrm{H} / \mathrm{L}$ communities [28]. Understanding the role of these factors could help to explain this populations' increased risk. While the burden of U.S. disparities in AD is associated directly with social disparities, racial and ethnic disparities could be explained in part by differences in susceptibility to vascular disease.

\section{ET-1 System and Regulation}

ET-1 was first isolated by Yanagisawa et al. in 1988 from cell culture supernatant of porcine aortic endothelial cells; the team referred to the factor as endothelin, which is now referred to as ET-1 [29]. Yanagisawa et al. determined that a larger peptide of 39 amino acids represented a precursor of the smaller mature bioactive of ET-1 (29 amino acids), named Big Endothelin (Big ET-1) [29] (Figure 1). Big ET-1 was found to undergo proteolytic cleavage by ECE-1. ET-1 was recognized as a potent, long-lasting endothelium-derived vasoconstrictive peptide and is the principal isoform in the human cardiovascular system [29]. Via two $G$ protein-coupled receptors, endothelin receptor type $\mathrm{A}_{\left(\mathrm{ET}_{\mathrm{A}}\right)}$ and endothelin receptor type $\mathrm{B}\left(\mathrm{ET}_{\mathrm{B}}\right)$, ET-1 may induce vasoconstriction, vasodilation, and vascular cell proliferation on resident vessels of the vascular system [30-33]. Along with its effects on vascular endothelial cells, ET-1 also may induce vascular smooth cell proliferation, mediated via $\mathrm{ET}_{\mathrm{A}}$ and $\mathrm{ET}_{\mathrm{B}}[34,35]$ (Figure 1). As described, the ET system consists of three major components: (1) ET-1; (2) ECE-1 (four isoforms of ECE-1 exist in humans (ECE-1a, ECE-1b, ECE-1c, and ECE-1d)), which is responsible for the biosynthesis of the active ET peptide [36]; and (3) ET receptors $\left(\mathrm{ET}_{\mathrm{A}}\right.$ and $\mathrm{ET}_{\mathrm{B}}$ ), which mediate the biological effects of this peptide [37,38] (Figure 1). In disease states, dysregulation 
of receptor expression may lead to uncontrolled vasoconstriction and cell proliferation by ET-1. The endothelin family is comprised of three members (ET-1, ET-2, and ET-3) of structurally similar 21 amino acid peptides that are cleaved from their respective Big ET-1 precursors [39]. ET-1 and ET-2 both bind $\mathrm{ET}_{\mathrm{A}}$ and $\mathrm{ET}_{\mathrm{B}}$ receptors with strong affinity [40], but ET-3 has a lower affinity for the $\mathrm{ET}_{\mathrm{B}}$ receptor [41] (Figure 1). The focus in this review is on ET-1, which is the parent compound of the endothelin family. ET-1 is not stored in cellular compartments but is generated in response to stimuli that include, but are not limited to, vasoconstrictive mediators, thrombogenic agents, cytokines, and growth factors, physiochemical factors, hormones, and certain drugs [42]. ET-1 is constitutive, secreted by endothelial cells, and released abluminally (Figure 2). ET-1 is regulated at the levels of transcription and has a half-life of approximately 15-20 min; however, its biological effects may last for two hours due to its affinity for its receptor post-endocytosis [42]. Venous plasma levels of ET-1 may be useful as an index for endothelial synthesis [42]. ET-1 clearance occurs by pulmonary and renal vascular beds via the $\mathrm{ET}_{\mathrm{B}}$ receptors through internalization and lysosomal degradation. Along with other endothelins, ET-1 also is degraded by neutral endopeptidases, which are mainly found in the brush border vesicles of kidney proximal tubules. This is significant in that individuals with chronic kidney disease have elevated plasma ET-1 levels; however, little or no changes in Big ET-1 levels were observed. ET-1 has two intramolecular disulfide bonds between cysteine residues that are crosslinked between positions 1 and 15 and 3 and 11, which is distinct among vasoactive mammalian peptides [43-45]. The binding of ET- 1 to $\mathrm{ET}_{\mathrm{A}}$ and $\mathrm{ET}_{\mathrm{B}}$ receptors requires prior proteolytic cleavage by ECE- 1 from Big ET-1 to facilitate receptor binding [46] (Figure 2). The abnormal folding of Big ET-1 prevents receptor interaction, and unlike the mature ET-1, Big ET-1 is resistant to proteolytic cleavage [47]. The different ET isoforms (ET-1, ET-2, and ET-3) are synthesized in three steps. Translation of a prepropeptide is present that undergoes proteolytic cleavage to yield a propeptides that are further cleaved by the enzyme furin to yield the Big ET precursors [48] (Figure 1). For example, Big ET-1 is cleaved by ECE-1 to yield the mature, biologically active ET-1. Notably, Big ET-1 is cleaved by ECE-1 at pH 7 and also by ECE-2 at pH 5.5 in endothelial cells [49]. Davenport et al. report that after release of ET-1 from endothelial cells, one in five molecules of Big ET-1 escapes cleavage by endothelial ECE-1, but this processing likely occurs by smooth muscle ECE or via alternative pathways catalyzed by chymase for ET-1 [49]. These studies suggest that ET-2 from endothelial cells is synthesized by a similar pathway. ET-3 is not released from human endothelial cells but is synthesized in other cells by ECE-1, with evidence for additional pathways [49]. ET-1 is the most abundant isoform and most studied in endothelial cells of the cardiovascular system. ET-1 is produced at lower levels by other cell types, including epithelial cells of the lungs, kidney, and colon; enteric glia cells, macrophages, and monocytes; and choroid plexus and certain neurons and reactive glial cells in the central nervous system, such as Sertoli cells, endometrial cells, hepatocytes, and breast epithelial cells [49]. The activation of $\mathrm{ET}_{\mathrm{A}}$ receptors by ET-1 leads to vasoconstriction via increases in cytosolic calcium levels, whereas the activation of $\mathrm{ET}_{\mathrm{B}}$ receptors through induction of endothelium-derived dilators, such as nitric oxide lead vasodilation (Figure 2). Therefore, the overall effects of ET-1 are represented by a balance between its interaction with $\mathrm{ET}_{\mathrm{A}}$ and $\mathrm{ET}_{\mathrm{B}}$ receptors. The hypotensive effects observed in the presence of the combined $\mathrm{ET}_{\mathrm{A}}$ and $\mathrm{ET}_{\mathrm{B}}$ receptor agonist suggest that the overall physiological effect of ET-1 is to increase blood pressure and maintain vascular homeostasis [50-52]. Figure 1, shows that the synthesis of ET-1, ET-2, and ET-3 occurs from separate mRNAs encoded by ET-1 gene variants EDN-1, EDN-2, and $E D N-3$. These preproendothelin mRNAs $1-3$ are translated to form preproendothelins $1-3$. 


\section{$A D$ and ADRD ?}

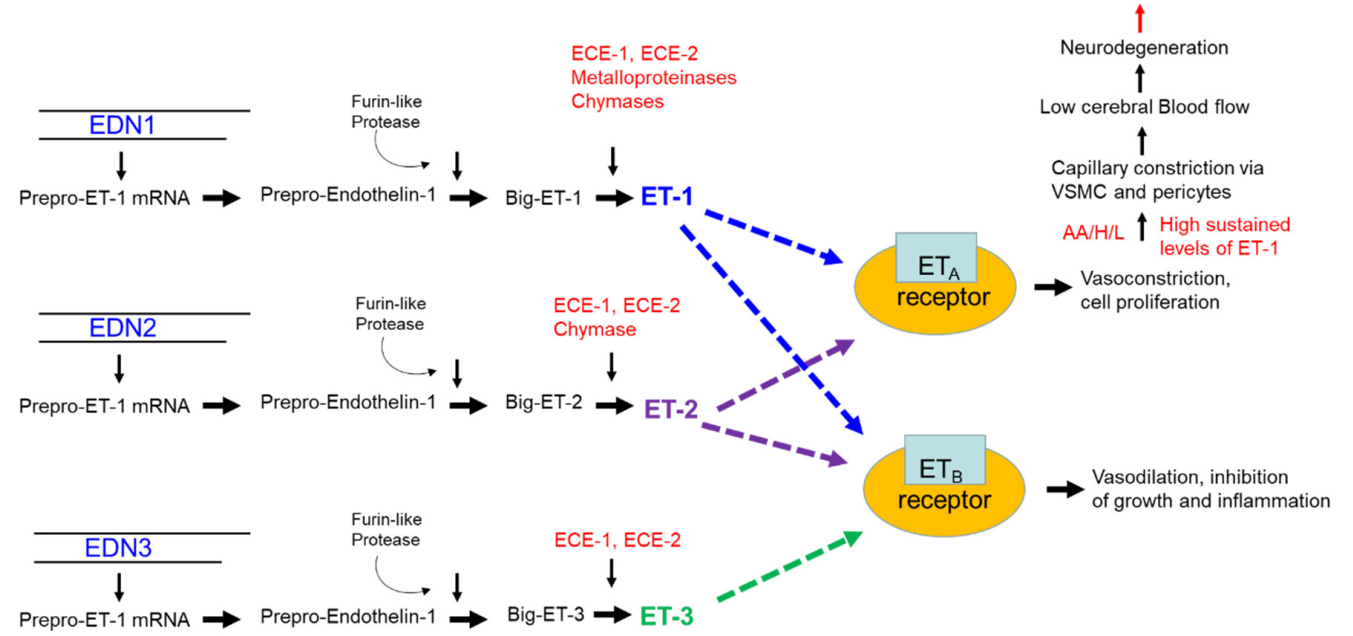

Figure 1. The endothelin system and its potential role in Alzheimer's disease (AD). The synthesis of Endothelin-1 (ET-1), ET-2, and ET-3 occurs from separate mRNAs encoded by EDN-1, EDN-2, and END-3. These preproendothelin mRNAs 1-3 are translated to form preproendothelins $1-3$. The three proteins are cleaved via furin-like protease to form Big ETs (Big ET-1, Big ET-2, and Big ET-3). Big-ETs are converted to the active peptide forms of ET-1 via ECE-1 and ECE-2, as well as by metalloproteinases and chymases, ET-2 via ECE-1, ECE-2 and chymase, and ET-3 via ECE-1 and ECE-2, respectively. The active forms bind to cognate $\mathrm{G}$-protein receptors $\mathrm{ET}_{\mathrm{A}}$ and $\mathrm{ET}_{\mathrm{B}}$ to activate cellular functions via $\mathrm{ET}_{\mathrm{B}}$ receptor binding by ET-1-3, resulting in vasodilation and inhibition of growth and inflammation; ET-1 and ET-2 may activate cellular function by binding to $\mathrm{ET}_{\mathrm{A}}$ receptors on vascular smooth muscle cells (VSMC) and pericytes in the brain and induce vasoconstriction, and cell proliferative responses. High sustained levels of ET-1 among AA and possibly Hispanic/Latino (H/L) populations at high risk for AD could predispose them to conditions of low cerebral blood flow (CBF), leading to neurodegeneration that could contribute to AD and Alzheimer's disease related dementias (ADRD).

\section{ET-1 Overexpression in brain capillaries: Implications for vasoconstriction and reduce cerebral blood flow in $A D$ and $A D$ associated dementias}

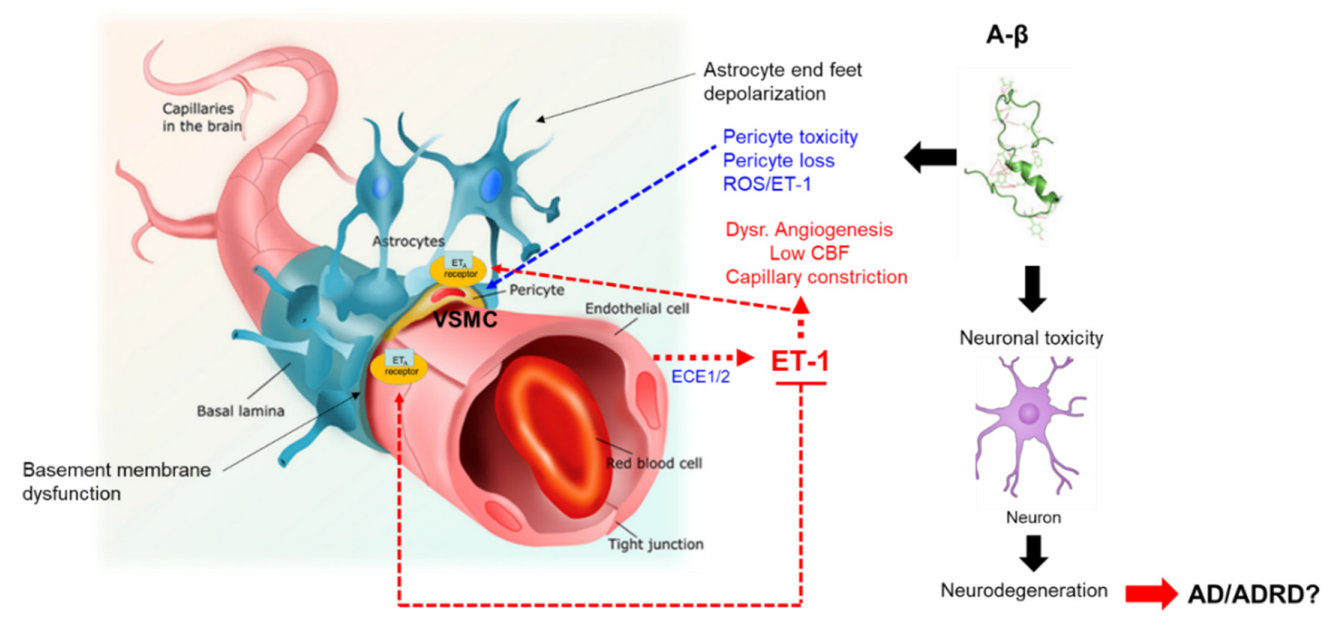

Figure 2. Pathophysiology in dysregulation of the ET-1 system with implications for AD. A theoretical model of the effects of ET- 1 and A $\beta$ proteins on VSMC and pericyte functions, respectively, in capillaries and components of the neurovascular unit. The effects of ET-1 on VSMC and pericytes include vasoconstriction, the disruption of angiogenesis leading to low CBF. The effects of $A \beta$ proteins on pericytes include pericyte loss and toxicity, induction of ROS, and capillary constriction, all contributing to neuronal toxicity and neurodegeneration that may contribute to AD and ADRD. Note: Figure 2, was revised from a previous report by Alcendor [53]. For the original figure, I acknowledge Pearson Education, Inc. (2014). 


\section{ET-1 System and AD in Minority Populations}

It is well known that AD patients have reduced cerebral blood flow that precedes the associated dementia and may contribute to its progression. ET-1 has been implicated as having a role in perfusion of all organ systems in humans. ET-1 synthesis occurs in all vessels of the body and is thought to contribute to the maintenance of basal vascular tone. However, dysregulation of the ET-1 system has been implicated in the pathogenesis of inflammation, arterial hypertension, atherosclerosis, cardiovascular disease, renal failure, coronary artery disease, cerebrovascular disease, pulmonary arterial hypertension, and sepsis [50]. Male gender, African ethnicity, and older age has been associated with elevated plasma levels of ET-1.

Evans et al. observed racial and gender differences in ET-1 plasma levels. The study, which involved healthy nonsmoking AA and NHW female and male volunteers between the ages of 18 and 70, was designed to determine plasma ET-1 levels by radioimmunoassay in healthy adults. Levels of plasma ET-1 ranged from $1.8 \mathrm{pg} / \mathrm{mL}$ to $16 \mathrm{pg} / \mathrm{mL}$ (mean $6.7 \mathrm{pg} / \mathrm{mL}$ ) in AAs and between $0.5 \mathrm{pg} / \mathrm{mL}$ and $12 \mathrm{pg} / \mathrm{mL}$ (mean $5.5 \mathrm{pg} / \mathrm{mL}$ ) in NHWs. In addition, plasma ET-1 levels were found to be higher in women than in men $(7.1+/-3.2$ vs. $4.5+/-3.6 ; p<0.01)$. AA men have significantly higher ET-1 levels when compared with NHW men (mean $6.2+/-0.8$ vs. $3.7+/-0.4 ; p<0.01$ ). The authors explain that the 2-fold increase in plasma ET-1 levels could predispose AA men to left ventricular hypertrophy and other cardiovascular diseases [54]. In this study, AA women, NHW women, and AA men have similar ET-1 levels, suggesting that the higher ET-1 levels observed in women as a group would be offset by estrogen in premenopausal women that would offer protection against the detrimental effects of high ET-1 levels [54]. Grubbs et al. examined the effects of race on mRNA and protein levels of ECE-1 subisoforms, ET-1, and ET receptor profiles using saphenous vein specimens from AA $(n=13)$ and NHW $(n=15)$ patients undergoing coronary artery grafting surgery [55]. The research team concluded ECE-1a was upregulated approximately 2- and 3-fold, respectively, in AAs. $\mathrm{ET}_{\mathrm{A}}$ receptor expression was higher in NHWs compared with $\mathrm{AAs}$, and $\mathrm{ET}_{\mathrm{B}}$ mRNA levels were 3-fold higher in $\mathrm{AAs}$, suggesting that the vasoconstriction-promoting $\mathrm{ET}_{\mathrm{B}}$ receptors are increased in AAs [55]. ET-1 and ECE-1 levels also were found to be higher in AAs compared with NHWs [55]. The small number of patients enrolled was a limitation in this study.

The role of the ET-1 system in AD development, particularly in minority populations, is largely unknown and represents an important knowledge gap in our understanding of the interactions between the ET- 1 system and A $\beta$ proteins in the development of AD. ET-1, a potent vasoconstrictive peptide, has been proposed as having a role in racial differences in stress reactivity [56]. In a study by Treiber et al., AAs exhibited higher absolute plasma ET-1 levels and greater increases in ET-1 in response to stressors, supporting a racial difference in hemodynamic reactivity to stress [56]. A study by Nortley et al. suggests that ET-1, which interacts with $\mathrm{ET}_{\mathrm{A}}$ receptors, may cause pericyte contractions, subsequent capillary constriction, and chronic hypoperfusion of the brain microvasculature in AD patients [57]. In a study that explored whether ethnic differences in ET-1 vascular activity exist in AA and NHW adults, Campia et al. found that hypertensive AAs had enhanced $\mathrm{ET}_{\mathrm{A}}$-dependent vasoconstrictor tone, likely due to increased production of ET-1 [58]. However, knowing the adverse vascular effects of sustained high levels of ET-1, this condition could predispose AAs to cerebrovascular disease that could impact development and/or progression of AD [58] (Figure 2). To our knowledge, studies involved in the dysregulation of the ET-1 system in AAs with AD largely have been unexplored. Identifying differences in ET-1 regulation in AD that induce capillary constriction by brain pericytes in AAs and NHWs would provide information to help explain racial and ethnic disparities in AD, which could contribute to the development of novel treatment strategies for targeting the ET-1 system in AAs and NHWs. The interactions between brain pericytes and the ET-1 system in AAs also deserves further investigation. We are aware that $\mathrm{AD}$ is a multifactorial disease and that other non-biological social risk factors that predispose AAs to AD exist, such as access to health care, poverty, being less likely to seek medical care, and clinically presenting later than ideal in the disease course [59-62]. In addition, psychosocial risk factors are thought to have a role in elevating plasma ET-1 levels that have been 
associated with an increased risk for cardiovascular disease [63]. In a small study, authors observed a positive correlation between chronic mental stress and elevated plasma ET-1 levels in AA males [63]. Cooper et al. observed a correlation between increased levels of plasma ET-1 in AAs with higher levels of perceived ethnic discrimination when compared with NHWs [64]. Plasma ET-1 also was shown to be higher among NHWs with low socioeconomic status [64].

\section{ET-1 and A $\beta$ Interactions}

ET-1, a potent vasoconstrictor that likely contributes to reduced blood flow in AD ischemia, has been shown to increase $A \beta$ production both in vitro and in vivo [65]. It has been reported that ET-1 exacerbated A $\beta$ deposition, tau phosphorylation, and cognitive impairment after intracerebral injection of $A \beta$ in rats. Palmer et al. discovered that the concentration of ET- 1 was higher in AD than in controls in both the cerebral cortex and cerebral blood flow [66]. Cultivation and exposure of human brain endothelial cells exposed $A \beta 40$ and $A \beta 42$, resulting in the release of ET- 1 with higher amounts observed after exposure to $A \beta 40$ compared with $A \beta 42$; this ET- 1 release could be abrogated with the addition of superoxide dismutase [67]. Palmer et al. also observed ECE-1 activity and ET-1 levels elevated in leptomeningeal blood vessels from postmortem brains of AD patients when compared with control tissue [67]. The authors conclude that the A $\beta$ induction of cerebral vasoconstriction likely is due in part by ECE-1 activity and ET-1 levels [67]. Nortley et al. suggest that brain vascular pericytes link $\mathrm{A} \beta$ to vascular dysfunction in $\mathrm{AD}$ [57] (Figure 2). Reports from human brain slices and a mouse model reveal that oxidative stress triggered by toxicity of $A \beta$ causes constriction of capillaries via the generation of reactive oxygen species (ROS) by the induction of reduced nicotinamide adenine dinucleotide phosphate oxidase 4 [57]. ROS then triggers the release of ET-1, which interacts with $\mathrm{ET}_{\mathrm{A}}$ receptors to cause pericyte contraction and subsequent capillary constriction [57] (Figure 2). Pericyte-mediated constriction of brain capillaries may result in chronic hypoperfusion of the brain microvasculature that likely contributes to neurodegeneration and cognitive decline observed in AD (Figure 2). An additional study by Palmer et al. suggests that the contribution of $A \beta$ accumulation or reduction in local microvascular blood flow in AD brains by ECE- 1 is a marginal finding with no significant differences in ECE-1 mRNA and protein levels in AD, vascular dementia, or control brains [68].

Paris et al. examined effects of $A \beta$ in isolated human cerebrovessels and in a transgenic mouse model of AD to determine the effects on ET-1 levels [69]. The authors observed that enhanced ET-1 induces vasoconstriction via solubilized $A \beta$ in isolated human middle cerebral and basilar arteries [69]. The vasoactive effects were abrogated with the cyclooxygenase-2 inhibitor SB202190, a specific p38 mitogen-activated protein kinase inhibitor (SB202190) [69]. The vasoconstrictive effects also were observed in the double transgenic APPsw AD (PS1/APPsw) mouse model that exhibited improvement upon administration of NS-398 or SB202190 [69].

\section{Genetics and ET-1 Dysregulation and Racial Disparities in AD}

The role of the gene variant EDN-1 on AD is unknown. High plasma ET-1 levels, along with a genetic predisposition to develop vascular disease, could contribute to AD progression and pathology over a life course. A study by Liang et al. reports that a genetic link of five tagSNPs (rs6458155, rs4145451, rs9369217, rs3087459, and rs2070699) in the EDN-1 gene to coronary artery disease is present in a Chinese Han population [70]. This is the first report of genetic polymorphisms in the EDN-1 gene linked to an associated risk for disease in a cohort of 525 coronary artery disease patients and 675 control subjects [70]. The authors suggest that these polymorphisms are associated with high circulating levels of ET-1 [70]. Verweij et al. initiated a genome-wide association study on plasma levels of midregional proadrenomedullin and C-terminal-pro-ET-1 (CT-pro-ET-1) (a biologically stable surrogate for ET-1), which at high levels are predictors of heart disease and heart failure [71]. The team examined common genetic variants in 3444 subjects of European descent and performed genotyping for SNPs, showing levels of associations and significance for 3230 subjects; a minor variant rs 2731672 was associated with 
higher CT-pro-ET-1 levels ( $p=1.23 \times 10^{-122}$ and $p=1.26 \times 10^{-67}$, respectively) [71]. Furthermore, the EDN-1 variant rs5370 was associated with elevated levels of CT-pro-ET-1 $\left(p=1.49 \times 10^{-27}\right)$ [71]. This study emphasizes the significance of genetic variation in the EDN-1 variant and its precursors and their link to vascular disease. Existing genetic-linked disparities for vascular disease among minority populations in the U.S., such as hypertension, diabetes, cardiovascular disease, kidney disease, and AD, supports the notion that $E D N-1$ gene variants may exist, which could result in a predisposition to having long-term high ET-1 levels, particularly in AA males. The broad implications of the long-term vasoconstrictive effects of high ET-1 levels in vascular tissues that express $\mathrm{ET}_{\mathrm{A}}$ receptors likely would contribute to cerebrovascular disease that could predispose AA males to AD. Genetic polymorphisms that could lead to increased expression levels of ET- 1 and its receptors $\left(\mathrm{ET}_{\mathrm{A}}\right.$ and $\left.\mathrm{ET}_{\mathrm{B}}\right)$ among $\mathrm{AA}$ males deserves further investigation. Understanding genetic polymorphisms that lead to dysregulation of endothelins and their receptors could provide information for the development of novel therapies, as well as provide better targeting of existing therapies for minority populations who are at greater risk for $\mathrm{AD}$.

\section{Potential Therapeutics for ET-1 Dysregulation in AD}

Dysregulation of ET- 1 and its interactions with cognate receptors $\mathrm{ET}_{\mathrm{A}}$ and $\mathrm{ET}_{\mathrm{B}}$ could be important risk factors for the development and/or progression of AD. The inherent prevalence of elevated ET-1 levels in AAs could serve as a driver for racial disparities in AD. Targeting of the human endothelin system would be an important strategy for the development of novel AD treatment therapies, particularly in minority communities at greater risk. ET-1-induced vasoconstriction, resulting in cerebral hypoperfusion, may impair neuronal function, reduce $A \beta$ and toxic metabolites clearance from the brain, and upregulate $A \beta$ production. Endothelin receptor antagonists (ERAs) may serve a role in the attenuation or prevention of $\mathrm{AD}$.

\subsection{Endothelin Receptor Agonist and Antagonists}

Studies by Palmer et al. revealed that the ERA bosentan could preserve aortic and carotid endothelial function in Tg2576 mice, suggesting that this agonist could be useful in altering low cerebral blood flow in AD [72]. Currently, three endothelin receptor antagonists are approved for use in the U.S.: (1) bosentan (2001, Tracleer $\left.{ }^{\circledR}\right)$; (2) ambrisentan (2007, Letairis $\left.{ }^{\circledR}\right)$; and (3) macitentan $\left(2013\right.$, Opsumit $\left.{ }^{\circledR}\right)$ [73]. Sitaxsentan [74], a fourth endothelin receptor blocker, was approved in Europe, but it is not approved in the U.S. and has been withdrawn from Europe due to severe liver injury linked to its use. These ERAs were developed to block the vasoconstrictive effects of endothelin-A receptors and license for the treatment of pulmonary arterial hypertension (PAH). The role of ERAs in the treatment of $\mathrm{AD}$ is unknown; however, both ECE-1 and ECE-2 are important for degradation and prevention of $A \beta$ accumulation in the brains of AD patients [75,76]. Still, ECE2 null mice develop a loss of learning and memory that mimic disabilities observed in AD patients [77]. Selective antagonists $\left(\mathrm{ET}_{\mathrm{A}} / \mathrm{ET}_{\mathrm{B}}\right) \mathrm{IRL}-1620 / \mathrm{PMZ}-1620580$ currently are being examined as novel therapies for the treatment of $\mathrm{AD}$-associated pathologies [78]. Elucidation of the crystal structure of the $\mathrm{ET}_{\mathrm{B}}$ receptor by Nagiri et al. revealed that the $\mathrm{ET}_{\mathrm{B}}$ receptor antagonists IRL-2500 and IRL-1620.90 functioned as inverse agonists that stabilize the inactive conformation of the receptor $[79,80]$. This results in drug-dependent stabilization of the receptor antagonists that leads to changes in functionality, likely contributing to their effectiveness and resulting side effects. A more comprehensive review of agonists and antagonists developed over the years for the endothelin system may be found in a review by Matthias Barton and Masashi Yanagisawa [81]. Taken together, the role of ERAs in the treatment or management of AD is unknown and requires further study.

\subsection{Endothelin Vaccines}

In a study for a novel PAH treatment, Dia et al. developed a vaccine (ETRQß-002) against the ET-1 receptor $\left(\mathrm{ET}_{\mathrm{A}}\right) \mathrm{ET}_{\mathrm{A}}$ peptide $\left(\mathrm{ET}_{\mathrm{A}}-002\right.$, second extracellular loop of $\mathrm{ET}_{\mathrm{A}}$ receptor, 
conjugated to the $Q \beta$ bacteriophage virus-like particle carrier protein, ETRQ $\beta$-002) [82]. Effects of the antibodies on $\mathrm{Ca}^{2+}$-dependent signal transduction events were examined in monocrotaline (MCT) and Sugen/hypoxia-induced pulmonary hypertension rats [82]. Monoclonal antibodies to $\mathrm{ET}_{\mathrm{A}}-002$ reduced remodeling of pulmonary arterioles and the right ventricle in MCT- and Sugen/hypoxia-induced PAH animals and decreased right ventricular systolic pressure [82]. This is a novel therapeutic approach to treat PAH, a chronic fatal disease that is associated with ET-1 dysregulation. Endothelin receptor agonist inhibits the binding of endothelin to its cognate receptor. Zhang et al. developed the monoclonal antibody getagozumab that targets the endothelin receptor $\mathrm{ET}_{\mathrm{A}}$ [83]. The antibody significantly lowers pulmonary arterial pressure in both hypoxia- and MCT-induced PAH monkey models and further attenuates the pulmonary arterial and right ventricular hypertrophy in MCT-induced PAH monkeys [83]. Getagozumab was found to be safe, long-lasting, and effective in treating PAH [83].

\section{Potential Role of Endothelin-1 and Other Endothelin-1-Related Molecules as Biomarkers in Biofluids for AD}

Plasma ET-1 levels in humans have been examined extensively, however ET-1 and its converting enzymes presence in other biofluids will require further investigation. Non-invasive means of examining ET-1 and its related converting enzymes and their potential correlations with AD plasma levels of ET-1 could provide surrogate biomarkers for plasma ET-1 in AD. ET-1 is found in urine however the synthesis of urinary ET-1 is primarily made by cells of the kidney and would not correlate with ET-1 levels in plasma [84]. However, Gurusankar et al., have shown a positive correlation between saliva and plasma levels of endothelin isoforms. [85]. This study showed a statistically significant positive correlation among endothelin isoforms in saliva and plasma for big endothelin-1, ET-1, and ET-3 [85]. However, ET-2 was not significantly correlated with other isoforms in either plasma or saliva [85]. The authors suggest that there is coordinated regulation of ET-1 and ET-3 but not ET-2. Saliva ET-1 levels could serve as a non-invasive surrogate marker for plasma ET-1 levels examined in AD. The presence of ET-1 has been observed in human breast milk; however, the correlation with ET-1 isoforms in plasma requires further investigation [86]. The highest concentrations of ET-1 were observed on the third day of lactation in postpartum lactating women [87]. Foremilk samples on third day postpartum contained significantly higher concentrations of ET-1, compared to hindmilk samples [87]. However, the correlation with plasma ET-1 levels relevant to AD has not been performed.

\section{Conclusions}

Dysregulation of the ET-1 system disproportionately may affect the development of cerebral vascular disease in the brains of different ethnic populations with AD. Understanding this system could provide information to explain racial and ethnic disparities in $\mathrm{AD}$, lead to the development of tools for early detection of minor cognitive disorders, and support early interventions targeting components of the ET- 1 system to limit progression of AD and ADRDs. The role of endothelin receptor agonists, antagonists, and vaccines as therapeutic interventions for treatment of $A D$ and ADRDs will require further investigation in the form of additional animal studies that could lead to randomized-controlled trials.

Funding: D.J.A. was supported by the Research Centers in Minority Institutions (RCMI) program grant (U54MD007586-01).

Acknowledgments: The author would like to thank Waldemar Popik and James E.K. Hildreth for reviewing and reading the manuscript.

Conflicts of Interest: The author declares no conflict of interest. 


\section{Abbreviations}

$\begin{array}{ll}\text { AAs } & \text { African Americans } \\ \text { A } \beta & \text { Amyloid beta protein } \\ \text { AD } & \text { Alzheimer's disease } \\ \text { ADRD } & \text { Alzheimer's disease and related dementias } \\ \text { APPsw AD } & \text { Transgenic mouse mode for Alzheimer's disease } \\ \text { CT-pro-ET-1 } & \text { C-terminal-pro-ET-1 } \\ \text { DM } & \text { Diabetes mellitus } \\ \text { ECE-1 } & \text { Endothelin-converting enzyme-1 } \\ \text { ECE-2 } & \text { Endothelin-converting enzyme-2 } \\ \text { EDN-1 } & \text { Endothelin-1 gene locus } \\ \text { EDN-2 } & \text { Endothelin-2 gene Locus } \\ \text { EDN-3 } & \text { Endothelin-3 gene Locus } \\ \text { ERAs } & \text { Endothelin receptor antagonists } \\ \text { ET } & \text { Endothelin receptor type A } \\ \text { ET } B & \text { Endothelin receptor type B } \\ \text { ET-1 } & \text { Endothelin-1 } \\ \text { ET-2 } & \text { Endothelin-2 } \\ \text { ET-3 } & \text { Endothelin-3 } \\ \text { H/L } & \text { Hispanic/Latino } \\ \text { NHWs } & \text { Non-Hispanic Whites } \\ \text { NS-398 } & \text { COX-2 inhibitor } \\ \text { PS1/APPsw } & \text { Transgenic mouse mode for Alzheimer's disease } \\ \text { ROS } & \text { Reactive oxygen species } \\ \text { SB202190 } & \text { Specific inhibitor of p38 MAPK signaling pathway } \\ \text { SCUBE2 } & \text { Signal peptide-CUB-EGF-like-containing protein 2 } \\ \text { tagSNPs } & \text { Tagged single nucleotide polymorphisms } \\ \text { T2DM } & \text { Type 2 diabetes mellitus } \\ & \end{array}$

\section{References}

1. Novak, P.; Chu, J.; Ali, M.M.; Chen, J. Racial and Ethnic Disparities in Serious Psychological Distress among Those with Alzheimer's Disease and Related Dementias. Am. J. Geriatr. Psychiatry 2019, 19, 30473-30477.

2. Clark, L.R.; Norton, D.; Berman, S.E.; Johnson, S.C.; Bendlin, B.B.; Wieben, O.; Turski, P.; Carlsson, C.; Asthana, S.; Gleason, C.E.; et al. Association of Cardiovascular and Alzheimer's Disease Risk Factors with Intracranial Arterial Blood Flow in Whites and African Americans. J. Alzheimers Dis. 2019, 72, 919-929. [CrossRef]

3. Potter, G.G.; Plassman, B.L.; Burke, J.R.; Kabeto, M.U.; Langa, K.M.; Llewellyn, D.J.; Rogers, M.A.; Steffens, D.C. Cognitive performance and informant reports in the diagnosis of cognitive impairment and dementia in African Americans and whites. Alzheimers Dement. 2009, 6, 445-453.

4. Gianattasio, K.Z.; Prather, C.; Glymour, M.M.; Ciarleglio, A.; Power, M.C. Racial disparities and temporal trends in dementia misdiagnosis risk in the United States. Alzheimers Dement. 2019, 5, 891-898. [CrossRef] [PubMed]

5. Mayeda, E.R.; Glymour, M.M.; Quesenberry, C.P.; Whitmer, R.A. Inequalities in dementia incidence between six racial and ethnic groups over 14 years. Alzheimers Dement. 2016, 3, 216-224.

6. Treiber, F.A.; Jackson, R.W.; Davis, H.; Pollock, J.S.; Kapuku, G.; Mensah, G.A.; Pollock, D.M. Racial differences in endothelin-1 at rest and in response to acute stress in adolescent males. Hypertension 2000, 3, $722-735$. [CrossRef]

7. Ahmed, M.; Rghigh, A. Polymorphism in Endothelin-1 Gene: An Overview. Curr. Clin. Pharmacol. 2016, 3, 191-210.

8. Tsui, J.C.; Dashwood, M.R. A role for endothelin-1 in peripheral vascular disease. Curr. Vasc. Pharmacol. 2005, 4, 325-332. [CrossRef] 
9. Wager, O.F.; Chirst, G.; Wojta, J.; Vierhapper, H.; Parzer, S.; Nowotny, P.J. Polar secretion of endothelin-1 by cultured endothelial cells. J. Biol. Chem. 1992, 267, 16066-16068.

10. Dehouck, M.P.; Vigne, P.; Torpier, G.; Breittmayer, J.P.; Cecchelli, R.; Frelin, C. Endothelin-1 as a mediator of endothelial cell-pericyte interactions in bovine brain capillaries. J. Cereb. Blood Flow Metab. 1997, 4, 464-469.

11. Ergul, A.; Portik-Dobos, V.; Giulumian, A.D.; Molero, M.M.; Fuchs, L.C. Stress upregulates arterial matrix metalloproteinase expression and activity via endothelin A receptor activation. Am. J. Physiol. Heart Circ. Physiol. 2003, 5, 2225-2232. [CrossRef] [PubMed]

12. Li, X.; Song, D.; Leng, S.X. Link between type 2 diabetes and Alzheimer's disease: From epidemiology to mechanism and treatment. Clin. Interv. Aging 2015, 10, 549-560.

13. Ali, H.; Rustam, R.; Aprilia, D.; Arizal, C.; Gusadri, I.B.; Utami, P.R. Upregulation of SCUBE2 expression in dyslipidemic type 2 diabetes mellitus is associated with endothelin-1. Diabetes Metab. Syndr. 2019, 5, 2869-2872. [CrossRef]

14. Kostov, K.; Blazhev, A.; Atanasova, M.; Dimitrova, A. Serum Concentrations of Endothelin-1 and Matrix Metalloproteinases-2, -9 in Pre-Hypertensive and Hypertensive Patients with Type 2 Diabetes. Int. J. Mol. Sci. 2016, 8, 1182. [CrossRef] [PubMed]

15. Palmer, J.C.; Shabnam, B.; Kehoe, P.G.; Love, S. Endothelin-converting enzyme-2 is increased in Alzheimer's disease and up-regulated by A $\beta$. Am. J. Pathol. 2009, 1, 262-270. [CrossRef] [PubMed]

16. Yang, S.; Jin, H.; Zhu, Y.; Wan, Y.; Opoku, E.N.; Zhu, L.; Hu, B. Diverse Functions and Mechanisms of Pericytes in Ischemic Stroke. Curr. Neuropharmacol. 2017, 6, 892-905. [CrossRef] [PubMed]

17. Wilson, R.S.; Barnes, L.L.; Bennett, D.A.; Li, Y.; Bienias, J.L.; De Leon, C.M.; Evans, D.A. Proneness to psychological distress and risk of Alzheimer disease in a biracial community. Neurology 2005, 64, 380-382. [CrossRef]

18. Barnes, L.L.; Bennett, D.A. Alzheimer's disease in African Americans: Risk factors and challenges for the future. Health Aff. 2014, 4, 580-586. [CrossRef]

19. Krogstad, J.N. Fact Tank, News in the Numbers. Pew Research Center; Key Facts about How the U.S. Hispanic Population is Changing. Available online: http://www.pewresearch.org/fact-tank/2016/09/08/keyfacts-about-how-the-u-s-hispanic-population-is-changing/ (accessed on 12 November 2016).

20. US Census Bureau. Available online: https://www.census.gov/topics/population/data.html (accessed on 25 November 2016).

21. Xiong, C.; Luo, J.; Coble, D.; Folasade, A.; Kukull, W.; Morris, J.C. Complex interactions underlie racial disparity in the risk of developing Alzheimer's disease dementia. Alzheimers Dement. 2020, 4, 589-597. [CrossRef]

22. Alzheimer's Association. 2016 Alzheimer's disease facts and figures. Alzheimers Dement. 2016, 4, 459-569.

23. Mehta, K.M.; Yeo, G.W. Systematic review of dementia prevalence and incidence in United States race/ethnic populations. Alzheimers Dement. 2017, 1, 72-83. [CrossRef] [PubMed]

24. Chin, A.L.; Negash, S.; Hamilton, R. Diversity and disparity in dementia: The impact of ethnoracial differences in Alzheimer disease. Alzheimer Dis. Assoc. Disord. 2011, 3, 187-195. [CrossRef] [PubMed]

25. Wu, S.; Vega, W.A.; Resendez, J.; Jin, H. Latinos and Alzheimer's Disease: New Numbers Behind the Crisis. Projection of the Costs for US Latinos Living with Alzheimer's Disease through 2060. Available online: http://www.usagainstalzheimers.org/sites/default/files/Latinos-and-AD_USC_UsA2-Impact-Report. pdf (accessed on 3 December 2016).

26. Livney, M.G.; Clark, C.M.; Karlawish, J.H.; Cartmell, S.; Negrón, M.; Nuñez, J.; Xie, S.X.; Entenza-Cabrera, F.; Vega, I.E.; Arnold, S.E. Ethnoracial differences in the clinical characteristics of Alzheimer's disease at initial presentation at an urban Alzheimer's disease center. Am. J. Geriatr. Psychiatry 2011, 5, 430-439. [CrossRef]

27. O’Bryant, S.E.; Johnson, L.; Balldin, V.; Edwards, M.; Barber, R.; Williams, B.; Devous, M.; Cushings, B.; Knebl, J.; Hall, J. Characterization of Mexican Americans with mild cognitive impairment and Alzheimer's disease. J. Alzheimers Dis. 2013, 2, 373-379. [CrossRef]

28. Vega, I.E.; Cabrera, L.Y.; Wygant, C.M.; Velez-Ortiz, D.; Counts, S.E. Alzheimer's Disease in the Latino Community: Intersection of Genetics and Social Determinants of Health. J. Alzheimers Dis. 2017, 4, 979-992. [CrossRef]

29. Yanagisawa, M.; Kurihara, H.; Kimura, S.; Tomobe, Y.; Kobayashi, M.; Mitsui, Y.; Yazaki, Y.; Goto, K.; Masaki, T. A novel potent vasoconstrictor peptide produced by vascular endothelial cells. Nature 1988, 332, 411-415. [CrossRef] [PubMed] 
30. Goto, K.; Hama, H.; Kasuya, Y. Molecular pharmacology and pathophysiological significance of endothelin. Jpn. J. Pharmacol. 1996, 4, 261-290. [CrossRef] [PubMed]

31. Miyauchi, T.; Masaki, T. Pathophysiology of endothelin in the cardiovascular system. Annu. Rev. Physiol. 1999, 61, 391-415. [CrossRef]

32. Thorin, E.; Clozel, M. The cardiovascular physiology and pharmacology of endothelin-1. Adv. Pharmacol. 2010, 60, 1-26.

33. Kitada, K.; Ohkita, M.; Matsumura, Y. Pathological Importance of the Endothelin-1/ETB Receptor System on Vascular Diseases. Cardiol. Res. Pract. 2012, 2012, 731970.

34. Hirata, Y.; Takagi, Y.; Fukuda, Y.; Marumo, F. Endothelin is a potent mitogen for rat vascular smooth muscle cells. Atherosclerosis 1989, 3, 225-228. [CrossRef]

35. Clozel, M.; Gray, G.A.; Breu, V.; Löffler, B.M.; Osterwalder, R. The endothelin ETB receptor mediates both vasodilation and vasoconstriction in vivo. Biochem. Biophys. Res. Commun. 1992, 186, 867-873. [CrossRef]

36. Takahashi, M.; Matsushita, Y.; Iijima, Y.; Tanzawa, K. Purification and characterization of endothelin-converting enzyme from rat lung. J. Biol. Chem. 1993, 268, 21394-21398. [PubMed]

37. Houde, M.; Desbiens, L.; D’Orléans-Juste, P. Endothelin-1: Biosynthesis, Signaling and Vasoreactivity. Adv. Pharmacol. 2016, 77, 143-175.

38. Stow, L.R.; Jacobs, M.E.; Wingo, C.S.; Cain, B.D. Endothelin-1 gene regulation. FASEB J. 2011, 1, 16-28. [CrossRef]

39. Inoue, A.; Yanagisawa, M.; Takuwa, Y.; Mitsui, Y.; Kobayashi, M.; Masaki, T. The human preproendothelin-1 gene. Complete nucleotide sequence and regulation of expression. J. Biol. Chem. 1989, 264, 14954-14959.

40. Arai, H.; Hori, S.; Aramori, I.; Ohkubo, H.; Nakanishi, S. Cloning and expression of a cDNA encoding an endothelin receptor. Nature 1990, 348, 730-732. [CrossRef]

41. Sakurai, T.; Yanagisawa, M.; Takuwa, Y.; Miyazaki, H.; Kimura, S.; Goto, K.; Masaki, T. Cloning of a cDNA encoding a non-isopeptide-selective subtype of the endothelin receptor. Nature 1990, 348, 732-735. [CrossRef]

42. Levin, E.R. Endothelins. N. Engl. J. Med. 1995, 333, 356-363. [CrossRef]

43. Huggins, J.P.; Pelton, J.T.; Miller, R.C. The structure and specificity of endothelin receptors: Their importance in physiology and medicine. Pharmacol. Ther. 1993, 59, 55-123. [CrossRef]

44. Janes, R.W.; Peapus, D.H.; Wallace, B.A. The crystal structure of human endothelin. Nat. Struct. Biol. 1994, 1,311-319. [CrossRef] [PubMed]

45. Wallace, B.A.; Janes, R.W. The crystal structure of human endothelin-1 and how it relates to receptor binding. J. Cardiovasc. Pharmacol. 1995, 26 (Suppl. 3), S250-S253. [CrossRef] [PubMed]

46. Russell, F.D.; Coppell, A.L.; Davenport, A.P. In vitro enzymatic processing of radiolabelled big ET-1 in human kidney. Biochem. Pharmacol. 1998, 55, 697-701. [CrossRef]

47. Peto, H.; Corder, R.; Janes, R.W.; Wallace, B.A. A molecular model for human Big-Endothelin-1 (Big ET-1). FEBS Lett. 1996, 394, 191-195. [CrossRef]

48. Xu, D.; Emoto, N.; Giaid, A.; Slaughter, C.; Kaw, S.; deWit, D.; Yanagisawa, M. ECE-1: A membrane-bound metalloprotease that catalyzes the proteolytic activation of big endothelin-1. Cell 1994, 78, 473-485. [CrossRef]

49. Davenport, A.P.; Hyndman, K.A.; Dhaun, N.; Southan, C.; Kohan, D.E.; Pollock, J.S.; Pollock, D.M.; Webb, D.J.; Maguire, J.J. Endothelin. Pharmacol. Rev. 2016, 68, 357-418. [CrossRef] [PubMed]

50. Shah, R. Endothelins in health and disease. Eur. J. Intern. Med. 2007, 4, 272-282. [CrossRef]

51. Haynes, W.G.; Ferro, C.J.; O’Kane, K.P.; Somerville, D.; Lomax, C.C.; Webb, D.J. Systemic endothelin receptor blockade decreases peripheral vascular resistance and blood pressure in humans. Circulation 1996, 93, 1860-1870. [CrossRef]

52. Haynes, W.G.; Webb, D.J. Contribution of endogenous generation of endothelin-1 to basal vascular tone. Lancet 1994, 344, 852-854. [CrossRef]

53. Alcendor, D.J. Interactions between Amyloid-B Proteins and Human Brain Pericytes: Implications for the Pathobiology of Alzheimer's Disease. J. Clin. Med. 2020, 5, 1490. [CrossRef]

54. Evans, R.R.; Phillips, B.G.; Singh, G.; Bauman, J.L.; Gulati, A. Racial and gender differences in endothelin-1. Am. J. Cardiol. 1996, 78, 486-488. [CrossRef]

55. Grubbs, A.L.; Anstadt, M.P.; Ergul, A. Saphenous vein endothelin system expression and activity in African American patients. Arterioscler. Thromb. Vasc. Biol. 2002, 7, 1122-1127. [CrossRef] [PubMed]

56. Treiber, F.A.; Kapuku, G.K.; Davis, H.; Pollock, J.S.; Pollock, D.M. Plasma endothelin-1 release during acute stress: Role of ethnicity and sex. Psychosom. Med. 2002, 5, 707-713. 
57. Nortley, R.; Korte, N.; Izquierdo, P.; Hirunpattarasilp, C.; Mishra, A.; Jaunmuktane, Z.; Kyrargyri, V.; Pfeiffer, T.; Khennouf, L.; Madry, C.; et al. Amyloid $\beta$ oligomers constrict human capillaries in Alzheimer's disease via signaling to pericytes. Science 2019, 6450, eaav9518. [CrossRef] [PubMed]

58. Campia, U.; Cardillo, C.; Panza, J.A. Ethnic differences in the vasoconstrictor activity of endogenous endothelin-1 in hypertensive patients. Circulation 2004, 25, 3191-3195. [CrossRef]

59. Manly, J.J.; Jacobs, D.; Mayeux, R. Alzheimer's disease among different ethnic and racial groups. In Alzheimer's Disease, 2nd ed.; Terry, R.D., Katzman, R., Bick, K.L., Sisodia, S.S., Eds.; Lippincott Williams and Wilkins: Philadelphia, PA, USA, 1999; pp. 117-131.

60. Chui, H.C.; Gatz, M. Cultural diversity in Alzheimer disease: The interface between biology, belief, and behavior. Alzheimer Dis. Assoc. Disord. 2005, 4, 250-255. [CrossRef]

61. Gilligan, A.M.; Malone, D.C.; Warholak, T.L.; Armstrong, E.P. Racial and ethnic disparities in Alzheimer's disease pharmacotherapy exposure: An analysis across four state Medicaid populations. Am. J. Geriatr. Pharmacother. 2012, 5, 303-312. [CrossRef]

62. Rovner, B.W.; Casten, R.J.; Harris, L.F. Cultural diversity and views on Alzheimer disease in older African Americans. Alzheimer Dis. Assoc. Disord. 2013, 2, 133-137. [CrossRef]

63. Yammine, L.; Kang, D.H.; Baun, M.M.; Meininger, J.C. Endothelin-1 and psychosocial risk factors for cardiovascular disease: A systematic review. Psychosom. Med. 2014, 76, 109-121. [CrossRef]

64. Cooper, D.C.; Mills, P.J.; Bardwell, W.A.; Ziegler, M.G.; Dimsdale, J.E. The effects of ethnic discrimination and socioeconomic status on endothelin-1 among blacks and whites. Am. J. Hypertens. 2009, 7, 698-704. [CrossRef]

65. Miners, J.S.; Palmer, J.C.; Tayler, H.; Palmer, L.E.; Ashby, E.; Kehoe, P.G.; Love, S. A $\beta$ degradation or cerebral perfusion? Divergent effects of multifunctional enzymes. Front. Aging Neurosci. 2014, 6, 238. [CrossRef] [PubMed]

66. Palmer, J.C.; Barker, R.; Kehoe, P.G.; Love, S. Endothelin-1 is elevated in Alzheimer's disease and upregulated by amyloid- $\beta$. J. Alzheimers Dis. 2012, 4, 853-861. [CrossRef] [PubMed]

67. Palmer, J.C.; Tayler, H.M.; Love, S. Endothelin-converting enzyme-1 activity, endothelin-1 production, and free radical-dependent vasoconstriction in Alzheimer's disease. J. Alzheimers Dis. 2013, 36, 577-587. [CrossRef] [PubMed]

68. Palmer, J.C.; Kehoe, P.G.; Love, S. Endothelin-converting enzyme-1 in Alzheimer's disease and vascular dementia. Neuropathol. Appl. Neurobiol. 2010, 36, 487-497. [CrossRef]

69. Paris, D.; Humphrey, J.; Quadros, A.; Patel, N.; Crescentini, R.; Crawford, F.; Mullan, M. Vasoactive effects of $\mathrm{A} \beta$ in isolated human cerebrovessels and inatransgenic mouse model of Alzheimer's disease: Role of inflammation. Neurol. Res. 2003, 25, 642-651. [CrossRef]

70. Liang, L.L.; Chen, L.; Zhou, M.Y.; Cai, M.Y.; Cheng, J.; Chen, Y.; You, S.K.; Chen, L.B.; Tang, Z.B.; Yang, X.L.; et al. Genetic susceptibility of five tagSNPs in the endothelin-1 (EDN1) gene to coronary artery disease in a Chinese Han population. Biosci. Rep. 2018, 5, BSR20171320. [CrossRef]

71. Verweij, N.; Mahmud, H.; Mateo Leach, I.; de Boer, R.A.; Brouwers, F.P.; Yu, H.; Asselbergs, F.W.; Struck, J.; Bakker, S.J.; Gansevoort, R.T.; et al. Genome-wide association study on plasma levels of midregional-proadrenomedullin and C-terminal-pro-endothelin-1. Hypertension 2013, 3, 602-608. [CrossRef]

72. Palmer, J.; Love, S. Endothelin receptor antagonists: Potential in Alzheimer's disease. Pharmacol. Res. 2011, 6, 525-531. [CrossRef]

73. Pulido, T.; Adzerikho, I.; Channick, R.N.; Delcroix, M.; Galiè, N.; Ghofrani, H.A.; Jansa, P.; Jing, Z.C.; Le Brun, F.O.; Mehta, S.; et al. SERAPHIN Investigators. Macitentan and morbidity and mortality in pulmonary arterial hypertension. N. Engl. J. Med. 2013, 9, 809-818. [CrossRef]

74. Widlitz, A.C.; Barst, R.J.; Horn, E.M. Sitaxsentan: A novel endothelin-A receptor antagonist for pulmonary arterial hypertension. Expert Rev. Cardiovasc. Ther. 2005, 6, 985-991. [CrossRef]

75. Pacheco-Quinto, J.; Eckman, C.B.; Eckman, E.A. Major amyloid- $\beta$-degrading enzymes, endothelin-converting enzyme-2 and neprilysin, are expressed by distinct populations of GABAergic interneurons in hippocampus and neocortex. Neurobiol. Aging 2016, 48, 83-92. [CrossRef] [PubMed]

76. Pacheco-Quinto, J.; Herdt, A.; Eckman, C.B.; Eckman, E.A. Endothelin converting enzymes and related metalloproteases in Alzheimer's disease. J. Alzheimers Dis. 2013, 33 (Suppl. 1), S101-S110. [CrossRef] [PubMed] 
77. Rodriguiz, W.; Gadnidze, R.M.; Ragnauth, K.; Dorr, N.; Yanagisawa, M.; Wetsel, W.C.; Devi, L.A. Animals lacking endothelin-converting enzyme-2 are deficient in learning and memory. Genes Brain Behav. 2008, 7, 418-426. [CrossRef] [PubMed]

78. Briyal, S.; Nguyen, C.; Leonard, M.; Gulati, A. Stimulation of endothelin B receptors by IRL-1620 decreases the progression of Alzheimer's disease. Neuroscience 2015, 301, 1-11. [CrossRef]

79. Nagiri, C.; Shihoya, W.; Inoue, A.; Kadji, F.M.N.; Aoki, J.; Nureki, O. Crystal structure of human endothelin ETB receptor in complex with peptide inverse agonist IRL2500. Commun. Biol. 2019, 2, 236. [CrossRef]

80. Shihoya, W.; Izume, T.; Inoue, A.; Yamashita, K.; Kadji, F.M.N.; Hirata, K.; Aoki, J.; Nishizawa, T.; Nureki, O. Crystal structures of human ETB receptor provide mechanistic insight into receptor activation and partial activation. Nat. Commun. 2018, 9, 4711. [CrossRef]

81. Barton, M.; Yanagisawa, M. Endothelin: 30 Years from Discovery to Therapy. Hypertension 2019, 6, 1232-1265. [CrossRef]

82. Dai, Q.Y.; Chen, X.; Song, X.; Chen, X.; Ma, W.; Lin, J.; Wu, H.; Hu, X.; Zhou, Y.; Zhang, H.; et al. Immunotherapy of Endothelin-1 Receptor Type A for Pulmonary Arterial Hypertension. J. Am. Coll. Cardiol. 2019, 20, 2567-2580. [CrossRef]

83. Zhang, V.C.; Wang, X.; Zhang, H.; Yao, C.; Pan, H.; Guo, Y.; Fan, K.; Jing, S. Therapeutic Monoclonal Antibody Antagonizing Endothelin Receptor A for Pulmonary Arterial Hypertension. J. Pharmacol. Exp. Ther. 2019, 1, 54-61. [CrossRef]

84. Raina, R.; Lou, L.; Berger, B.; Vogt, B.; Sao-Mai Do, A.; Cunningham, R.; Vasavada, P.; Herrmann, K.; Dell, K.; Simonson, M. Relationship of urinary endothelin-1 with estimated glomerular filtration rate in autosomal dominant polycystic kidney disease: A pilot cross-sectional analysis. BMC Nephrol. 2016, 17, 22. [CrossRef]

85. Gurusankar, R.; Kumarathasan, P.; Saravanamuthu, A.; Thomson, E.M.; Vincent, R. Correlation between Saliva and Plasma Levels of Endothelin Isoforms ET-1, ET-2, and ET-3. Int. J. Pept. 2015, 2015, 828759. [CrossRef] [PubMed]

86. Lam, H.C.; Takahashi, K.; Ghatei, M.A.; Warrens, A.N.; Rees, A.J.; Bloom, S.R. Immunoreactive endothelin in human plasma, urine, milk, and saliva. J. Cardiovasc. Pharmacol. 1991, 17 (Suppl. 7), S390-S393. [CrossRef]

87. Ken-Dror, S.; Weintraub, Z.; Yechiely, H.; Kahana, L. Atrial natriuretic peptide and endothelin concentrations in human milk during postpartum lactation. Acta Paediatr. 1997, 8, 793-795. [CrossRef] [PubMed]

Publisher's Note: MDPI stays neutral with regard to jurisdictional claims in published maps and institutional affiliations.

(C) 2020 by the author. Licensee MDPI, Basel, Switzerland. This article is an open access article distributed under the terms and conditions of the Creative Commons Attribution (CC BY) license (http://creativecommons.org/licenses/by/4.0/). 